dr hab. Dariusz Grygrowski

Uniwersytet Warszawski

Wydział Dziennikarstwa, Informacji i Bibliologii

dargry@uw.edu.pl

\title{
STRONA INTERNETOWA BIBLIOTEKI I JEJ SYSTEM ZINTEGROWANY JAKO NARZĘDZIA POZYSKIWANIA DODATKOWYCH FUNDUSZY
}

\author{
THE LibRARY's Website ANd ITS INTEgRATEd SYSTEM \\ as THE ToOls for RaIsing AdDitional Funds
}

\begin{abstract}
Abstrakt
Bibliotekarze $\mathrm{z}$ polskich bibliotek akademickich, zatrudnieni $\mathrm{w}$ oddziałach (ewentualnie na jednoosobowych stanowiskach), których zadaniem jest pozyskiwanie dodatkowych funduszy, w praktyce zajmują się głównie przygotowywaniem wniosków o środki z funduszy unijnych i programów rządowych. Tymczasem są metody mniej absorbujące czasowo, które stosowane systematycznie pozwalają również $\mathrm{w}$ znaczący sposób powiększać biblioteczne budżety. Są pewne działania fundraisingowe, rekomendowane w poradnikach anglojęzycznych, które w polskiej rzeczywistości, ze względu na różnice kulturowe, prawne i ekonomiczne, nie miałyby zastosowania lub nie byłyby odpowiednio skuteczne. Jest jednak także wiele metod, które są na tyle uniwersalne, że łatwo dałoby się je zastosować w polskiej praktyce. Przede wszystkim należy tu wymienić wykorzystanie strony internetowej biblioteki i interfejsu WWW bibliotecznego systemu zintegrowanego do powiększania kręgu donatorów. Celem artykułu jest więc omówienie najczęściej stosowanych metod pozyskiwania dodatkowych funduszy $\mathrm{z}$ wykorzystaniem strony internetowej biblioteki i jej systemu zintegrowanego. Podkreśla się, że fundraising sieciowy uprawiany za pośrednictwem strony internetowej biblioteki przynosi znaczące korzyści, uwzględniając proporcje między poniesionymi kosztami a uzyskanymi darowiznami. Niestety, polskie biblioteki w porównaniu z bibliotekami w innych rozwi-
\end{abstract}


niętych krajach, w bardzo niewielkim stopniu wykorzystują potencjał fundraisingowy swojej strony internetowej. Analiza wybranych stron internetowych, pod kątem dostępności informacji o sposobach wsparcia bibliotek, została uzupełniona metodą analizy piśmiennictwa.

Słowa kluczowe: fundraising biblioteczny, metody fundraisingu, fundraising sieciowy, podręczniki fundraisingu, strona internetowa biblioteki.

\begin{abstract}
The librarians in the Polish academic libraries, employed in the departments (or in the single offices), who are supposed to acquire additional funds, in practice deal primarily with preparing the applications for the grants from EU funds and government programmes. In the meantime, there are less time-absorbing methods that, when applied systematically, also allow to significantly increase the library budgets. There are some activities recommended in the English fundraising handbooks, which on account of cultural, legal and economic differences, would neither be applicable nor be appropriately effective in the Polish reality. However, there are also many methods which are universal enough so that it would be possible to apply them in the Polish practice. First of all, what should be pointed here is the use of the library's website and the WWW interface of the library integrated system for enlarging the circle of donors. Therefore, the aim of the article is to discuss the most frequently used methods of obtaining additional funds by using the library's website and its integrated system. The analysis of the selected websites, with regard to the availability of information on the ways of providing the support for the libraries, has been supplemented by a literature review. It is emphasized that the online fundraising, practiced via the library's website, brings considerable advantages, taking into account the proportion between the incurred costs and the obtained donations. Unfortunately, in the comparison to the libraries in the other developed countries, Polish libraries make hardly any use of the fundraising potential of their websites.
\end{abstract}

Keywords: library fundraising, fundraising methods, online fundraising, fundraising handbooks, library's website. 


\section{Fundraising sieciowy}

Upowszechnienie się Internetu, dla którego impulsem było pojawienie się ćwierć wieku temu stron WWW, spopularyzowanie poczty elektronicznej, a w dalszej kolejności powstanie nowych narzędzi kojarzonych z filozofią Web 2.0 sprawiło, że w działalności fundraisingowej otworzyło się nowe pole aktywności. Rozwinął się bowiem tzw. fundraising sieciowy (ang. online fundraising). Ta odmiana fundraisingu stała się na tyle istotna i specyficzna zarazem, że w podręcznikach z tego zakresu zamieszczane są odrębne rozdziały dotyczące właśnie różnych sposobów pozyskiwania funduszy za pośrednictwem sieci. W anglojęzycznych raportach i podręcznikach takie omówienia i porady pojawiają się najczęściej pod hasłami: „online fundraising” lub „online giving” czy „online donations".

Ostatnie badania agencji Dunham+Company, zajmującej się konsultingiem w zakresie fundraisingu pokazują, jak znacząco rośnie skuteczność pozyskiwania funduszy poprzez sieć. Przede wszystkim okazuje się, że wzrósł odsetek osób w wieku 40-59 lat, które w dokonywaniu darowizn wykorzystują tryb online. Badania z 2010 r. wykazały, że 47\% donatorów $\mathrm{z}$ tej grupy wiekowej wykonywało swój dobroczynny gest za pośrednictwem sieci. Natomiast w badaniach z 2015 r. ten odsetek wyniósł już 67\%. Wzrósł także odsetek osób, które decyzję o dokonaniu darowizny podjęły pod wpływem apeli przekazywanych w mediach społecznościowych. W $2014 \mathrm{r}$. ten odsetek wyniósł $20 \%$, a w 2015 wzrósł do $26 \%^{2}$. Z innych badań prowadzonych na zlecenie Dunham+Company wynika też stały wzrost liczby darowizn dokonywanych z użyciem urządzeń mobilnych - głównie smartfonów i tabletów ${ }^{3}$. A być może najlepsze wyniki, z punktu widzenia osób zajmujących się fundraisingiem, pokazują badania przeprowadzone na grupie osób powyżej $75 \mathrm{r}$. życia. Ta kategoria wiekowa jest bowiem w działalności fundraisingowej szczególnie ważna, bo darowizny od osób z tej grupy są kwotowo

1 Zob. np. K. Klein: Fundraising for social change. Seventh edition. Hoboken, New Jersey 2016 (Online fundraising, s. 151-162); Academic library fundraising benchmarks. New York 2014 (Online fundraising, s. 91-101).

2 Survey shows aging donors most likely to give online. Dunham+Company. Tryb dostępu: https://www.dunhamandcompany.com/2016/01/survey-shows-aging-donors-most-likely-to-give-online/ [22 czerwca 2017].

3 Dunham+Company study: explosive growth in donations via mobile devices. Dunham+Company. Tryb dostępu: https://www.dunhamandcompany.com/2016/03/ dunhamcompany-study-explosive-growth-in-donations-via-mobile-devices/ [22 czerwca 2017]. 
największe. Zatem najnowsze badania pokazują, że osoby w wieku 75+ coraz chętniej dokonują darowizn online, a łączna ich kwota jest wyższa niż suma darowizn dokonywanych przez osoby z pozostałych kategorii wiekowych ${ }^{4}$. $\mathrm{Z}$ badań tych wypływają więc dla bibliotek proste wnioski. Po pierwsze, obecność na stronie internetowej biblioteki elementów fundraisingu to podstawa w skutecznym pozyskiwaniu funduszy poprzez sieć. Po drugie, obecność biblioteki w mediach społecznościowych i aktywność odpowiedzialnych za to pracowników jest niezbędna i korzystna z punktu widzenia efektywności fundraisingowej. Po trzecie, responsywność strony WWW biblioteki na urządzeniach mobilnych to nie ekstrawagancja, a konieczność.

O tym, jak efektywną platformą pozyskiwania finansowego wsparcia jest Internet, świadczy zjawisko internetowego crowdfundingu, czego przykładem mogą być takie serwisy, jak działający od 2008 r. serwis o nazwie Indiegogo, czy bardziej popularny, a o rok młodszy serwis Kickstarter lub też CrowdRise (2010) i GoFundMe (2010), gdzie zgłaszane są różne projekty $\mathrm{z}$ nadzieją na uzyskanie społecznościowego finansowania. Powodzenie projektów korzystających z pomocy takich serwisów, które potrafily zebrać fundusze w wysokości przekraczającej czasem kilkadziesiąt razy kwotę oczekiwaną przez projektodawców, pokazuje jednocześnie ważną zasadę fundraisingu - również sieciowego - łatwiej jest mianowicie przekonać darczyńców i uzyskać wsparcie, gdy wskaże się konkretny cel, na który zebrane fundusze mają być przeznaczone.

Szczególnie zauważalny wzrost efektywności fundraisingu prowadzonego online nastąpił około 2012 r. Miesięcznik „The Chronicle of Philanthropy" podawał, że w $2012 \mathrm{r}$. w stosunku do roku poprzedniego organizacje nonprofit (a więc wśród nich także biblioteki) zanotowały wzrost kwoty darowizn pozyskanych online o $14 \%$. Oczywiście pod pojęciem „fundraisingu prowadzonego online" mieszczą się różne techniki, wśród których wymagająca aktywności metoda direct mailing jest szczególnie skuteczna. Ale nie wymagająca wielkiego wysiłku metoda wykorzystania własnej strony internetowej też powinna być tu wymieniona ${ }^{5}$.

4 Annual online study shows donors 75 and older now giving online. Dunham+Company. Tryb dostępu: https://www.dunhamandcompany.com/2017/03/annual-online-study -shows-donors-75-and-older-now-giving-online/ [22 czerwca 2017].

5 The Big Boom in online giving. „The Chronicle of Philanthropy” 2013, june 23. Tryb dostępu: https://www.philanthropy.com/article/The-Big-Boom-in-Online-Giving/150689 [20 czerwca 2017]. 
Informacje o swoich działaniach fundraisingowych biblioteki przekazują oczywiście na wszelkie możliwe sposoby. Wykorzystują więc z jednej strony sposoby tradycyjne, przygotowując plakaty, ogłoszenia czy rozdając czytelnikom w budynku biblioteki proste materiały drukowane. $\mathrm{Z}$ drugiej strony, wykorzystują coraz częściej kanały komunikacji elektronicznej, a strona internetowa biblioteki jest pierwszym i najlepszym miejscem, by zachęcić użytkowników do wsparcia biblioteki funduszami, pomocą materialną i wolontariatem.

\section{„Donate button” $\mathrm{i}$ inne elementy fundraisingu na stronie WWW}

Sformułowaną dekadę temu uwagę G. Holta i G. Horna, że biblioteki niedostatecznie wykorzystują własną stronę internetową w działaniach fundraisingowych, można z pewnością odnieść dziś do bibliotek w Polsce, ale w tych bibliotekach, których stwierdzenie Holta i Horna wówczas dotyczyło, a więc przede wszystkim w bibliotekach amerykańskich, wiele pod tym względem się zmieniło. Biblioteki te zdecydowanie dostrzegły potencjał stron internetowych w zabiegach o uzyskanie darowizn i innego wsparcia, o czym przekonuje bogactwo elementów fundraisingowych na ich stronach i częstokroć rozbudowanie tej części serwisu WWW biblioteki, gdzie mowa jest o różnych możliwościach wsparcia biblioteki funduszami lub zaangażowaniem w wolontariat.

Dodanie do strony internetowej biblioteki elementów fundraisingowych nie jest specjalnie kłopotliwe, a korzyść jest bezdyskusyjna, bo ułatwia to tym wszystkim użytkownikom biblioteki, którzy korzystają z jej strony i może chcieliby w postaci darowizny online wyrazić zadowolenie z usług świadczonych przez bibliotekę, dać wyraz swojej satysfakcji. Takich donatorów Holt i Horn nazywają cyberdarczyńcami (oryg. cyberspace donors) ${ }^{6}$.

Najczęściej spotykanym sposobem pozyskiwania funduszy za pośrednictwem serwisu internetowego biblioteki jest umieszczenie na stronie głównej hiperłącza zachęcającego do dokonania darowizny (ang. donate button). Podręcznik Amerykańskiego Stowarzyszenia Bibliotekarskiego ALA pt. Frontline Fundraising Toolkit zaleca bibliotekarzom wprost: „dodaj do strony internetowej przycisk »Donate«, co pozwoli użytkownikom doko-

6 G. E. Holt, G. Horn: Taking donations in cyberspace. „The Bottom Line” Vol. 18, nr 1 (2005), s. 25. 
nywać darowizn online"7. Co więcej, poradniki fundraisingu sieciowego podają, że "przycisk” zachęcający do darowizny powinien się pojawiać i wyróżniać na każdej z podstron serwisu WWW ${ }^{8}$.

$\mathrm{Z}$ pewnością są osoby, które zadadzą pytanie, jak skuteczny jest to zabieg i czy rzeczywiście znajdą się użytkownicy, którzy zechcą skorzystać z łącza „Podaruj” i wesprzeć bibliotekę swoim przelewem. Odpowiada na to poprzez pytanie retoryczne wspomniany podręcznik zaangażowanego fundraisingu ALA: „We give to almost everyone else online, why not the library?"9. Z europejskiego, a zwłaszcza polskiego punktu widzenia zdanie to może nie brzmieć zbyt przekonująco, bo przekazywanie darowizn $\mathrm{w}$ trybie online nie jest $\mathrm{u}$ nas wcale takie powszechne. Tymczasem potencjał społeczny i zaangażowanie $\mathrm{w}$ akcje charytatywne jest w USA dużo większe niż w naszej części świata. Amerykański potencjał filantropijny notuje najwyższe wskaźniki na świecie. To wynika nie tylko z zamożności tamtego społeczeństwa, ale też z pewnych czynników historyczno-kulturowych. Stale rosnący filantropijny potencjał społeczeństwa amerykańskiego potwierdzają coroczne raporty fundacji pod nazwą The Giving Institute (pod obecną nazwą działa od 2005 r., a powstała w 1935 r. jako American Association of Fund-Raising Counsel) publikowane od ponad 60 lat pt. Giving USA: The Annual Report on Philanthropy ${ }^{10}$. Nic dziwnego zatem, że elementy fundraisingu na stronach anglosaskich bibliotek są tak często spotykane, bo tam prośba o wsparcie pada rzeczywiście na podatny grunt.

Wstawienie na stronę internetową elementu o treści „Donate” lub podobnej, to tylko pozornie prosty zabieg, należy bowiem tak skonstruować tę część serwisu, by zbyt skomplikowane procedury nie zniechęciły donatorów. Należy więc przy projektowaniu strony WWW odpowiedzieć na pytanie, co ma nastąpić, gdy już potencjalny darczyńca „wciśnie” przycisk „Donate". Autorzy podręczników na temat fundraisingu sieciowego podają w tym zakresie prostą zasadę - im więcej kroków musi wykonać darczyńca, by dokonać darowizny online, tym większa jest możliwość, że straci swój

7 Frontline fundraising toolkit. American Library Association. Tryb dostępu: http://www. ala.org/advocacy/sites/ala.org.advocacy/files/content/advleg/advocacyuniversity/frontline_fundraising_toolkit/fft.pdf, s. 23 [20 czerwca 2017].

8 Online giving makes it easy for your supporters of all ages to donate. W: Online fundraising: the beginner's guide for nonprofits. Tryb dostępu: https://www.mobilecause.com/ beginners-guide-to-online-fundraising/online-giving [17 czerwca 2017].

9 Frontline fundraising toolkit, dz. cyt., s. 22.

10 Zob. The Giving Institute. Tryb dostęu: https://givingusa.org/ [17 czerwca 2017]. 
zapał i zrezygnuje $\mathrm{z}$ przelewu ${ }^{11}$. Należy też zadbać o to, by osoba chcąca dokonać darowizny online miała poczucie podstawowego bezpieczeństwa transakcji, co w pierwszej kolejności zapewni szyfrowanie komunikacji. W przypadku połączenia szyfrowanego użytkownik powinien zamiast standardowego wywołania http:// widzieć przed adresem internetowym biblioteki wywołanie https://12.

Najprostszym, choć mniej skutecznym rozwiązaniem z zastosowaniem przycisku „Donate”, jest umieszczenie w serwisie internetowym biblioteki podstrony, gdzie podawane są wszelkie informacje o potrzebach biblioteki i możliwych formach jej wsparcia. Na takiej stronie podawany jest też numer konta, na które donator może przelać finansowe wsparcie dla biblioteki. To jednak jest rozwiązanie mniej efektywne, bo wymaga od donatora większej aktywności i determinacji. Trzeba bowiem w takiej sytuacji skopiować numer konta biblioteki, a następnie zalogować się na stronie własnego banku i dokonać przelewu, wypełniając wszystkie wymagane pola w formularzu przelewu. Potrzeba wykonania dodatkowych czynności może zniechęcać mniej zdecydowanych potencjalnych donatorów. Nie powinno się więc przedłużać procedury darowizny online. Zmuszanie osoby wstępnie gotowej do dokonania darowizny do przechodzenia przez kolejne stadia przelewu zwiększa prawdopodobieństwo zmiany decyzji i odstąpienia od przelewu. Zwłaszcza nie jest wskazane wymaganie od potencjalnego darczyńcy, by $\mathrm{w}$ celu dokonania darowizny przeszedł rejestrację w systemie biblioteki. To $\mathrm{w}$ dużym stopniu grozi odstąpieniem od procedury przelewu ${ }^{13}$.

Dla beneficjenta, w tym przypadku biblioteki, korzystne jest więc uproszczenie procedury przelewu poprzez pominięcie dodatkowego logowania i wypełniania formularzy. Będzie to możliwe, gdy cała procedura będzie się rozpoczynać jeszcze na stronie biblioteki, a skuteczność pozyskiwania darowizn poprzez własną stronę internetową poprawi uruchomienie bramki płatności online. Osoba chcąca dokonać darowizny, zostanie wtedy bezpośrednio skierowana na stronę operatora płatności elektronicznych. Wymaga to nawiązania współpracy z wybranym systemem płatności internetowych i podpisania odpowiedniej umowy z serwisem obsługującym płatności online (np. PayPal, PayU, Przelewy24, Dotpay, Tpay).

11 Online giving makes it easy..., dz. cyt.

12 Tamże.

13 Beyond book sales. The complete guide to raising real money for your library. Ed. by S. Dowd. Chicago 2014, s. 128. 
Należy też dodać, że pod hiperłączem o treści „Donate” lub podobnej nie musi się znajdować wyłącznie formularz szybkiego przelewu określonej kwoty darowizny. Biblioteki nie oczekują bowiem od donatorów wyłącznie pieniędzy. Czasem więc biblioteki dodają informację, że obok darowizn finansowych przyjmują także darowizny materialne - przede wszystkim pozycje książkowe i materiały audiowizualne. Zazwyczaj jednak w tej części serwisu WWW biblioteki precyzują jednocześnie, jakiego rodzaju materiały są gotowe przyjąć w formie darowizny, a jakich nie przyjmą. Chodzi oczywiście o to, by zniechęcić osoby, które pod pozorem darowizny chciałyby się pozbyć materiałów mało wartościowych lub zniszczonych ${ }^{14}$. Zaleca się też, by w części fundraisingowej serwisu WWW biblioteki były podane główne zasady przyjmowania darowizn materialnych, $\mathrm{z}$ wyraźnym zastrzeżeniem, że tylko niektóre $\mathrm{z}$ podarowanych tytułów mogą zostać włączone do zbiorów, inne mogą być natomiast przeznaczone na kiermasz taniej książki lub poddane recyklingowi ${ }^{15}$.

Biblioteki, które doceniają fundraisingowy potencjał strony internetowej, potrafią znacznie rozbudować tę część swojego serwisu WWW, gdzie pojawiają się szczegółowe informacje o sposobach wsparcia biblioteki, a więc te podstrony, do których odsyła z głównej strony przycisk „Donate”. Przykładem może być rozbudowany w tym zakresie serwis WWW British Library, gdzie użytkownik znajdzie kilkanaście podstron $\mathrm{z}$ dokładnymi informacjami o tym, jakiego wsparcia oczekuje Biblioteka Brytyjska, jak zostać członkiem stowarzyszenia przyjaciół biblioteki, jak i na co przekazać darowiznę, jak dokonać zapisu majątkowego itp. Chociaż należy też zaznaczyć, że główna strona WWW Biblioteki Brytyjskiej nie do końca odpowiada zaleceniom podawanym $\mathrm{w}$ podręcznikach bibliotecznego fundraisingu. Bo oto hiperłącze odsyłające do informacji o możliwości wsparcia biblioteki, które na stronach innych bibliotek przybiera czasem postać wyróżniającego się graficznie elementu z hasłem typu: „Donate”, „Support Us”, "Get Involved” czy po prostu „Give”, na stronie BL znajduje się co prawda w głównym Menu, ale nie jest elementem w żaden sposób wyeksponowanym, a do tego stosowna zakładka opatrzona została lapidarnym słowem "Join”, co można przetłumaczyć jako „przyłącz się, dołącz do nas”. Dopiero w rozwijającym się z tej zakładki Menu pojawia się charakterystyczne

14 Zob. np. Vancouver Public Library - Donate Materials to VPL. Tryb dostępu: https:// www.vpl.ca/policy/donate-materials-vpl [17 czerwca 2017].

15 T. Cooper: Getting the most from donations. „Public Libraries” Vol. 49(2) (2010), s. 31-36. 
dla fundraisingu sieciowego hasło - „Support Us”, a pod nim rozgałęziona sieć stron zachęcających do darowizn i innych form wsparcia ${ }^{16}$.

Podobna sytuacja ma miejsce na stronie Biblioteki Kongresu w Waszyngtonie. Tam również część fundraisingowa serwisu WWW jest rozbudowana i podzielona na kilkanaście podstron, ale przycisk „Donate”, choć znajduje się na głównej stronie, jest niewielkim, niewyróżniającym się elementem, do tego umieszczonym nietypowo, bo w stopce strony ${ }^{17}$.

Typowa i polecana lokalizacja przycisku „Donate” na stronach bibliotek to prawy górny róg strony startowej. Dobrym przykładem jest strona Biblioteki Publicznej w Nowym Jorku w wersji z 2017 r., gdzie wszystkie pozycje $\mathrm{w}$ górnym menu utrzymane są $\mathrm{w}$ jednym kolorze, tylko pozycja "Donate” wyróżnia się na czerwonym tle. Skorzystanie z tego hiperłącza przenosi użytkownika na stronę, gdzie można wskazać jedną z pięciu kwot darowizny w wysokości 55, 115, 250, 500 i 1 tys. dolarów albo też wpisać własną kwotę. Można też zaznaczyć, że wskazana kwota ma być przekazywana na konto biblioteki co miesiąc. Potem już tylko pozostaje podanie swoich danych $\mathrm{w}$ formularzu przelewu i wybór formy płatności - kartą kredytową lub w systemie PayPal.

Obok łącza „Donate” na stronie nowojorskiej biblioteki znajduje się też inny ważny element bibliotecznego fundraisingu - łącze "Shop”, kierujące do sklepu internetowego, w którym można kupić wszelakie pamiątkowe gadżety: kubki, torby, breloczki do kluczy, wisiorki, koszulki i inne przedmioty. Nawet skarpety - oczywiście wszystko z logo biblioteki i jej nazwą. $\mathrm{Z}$ oferty sklepu internetowego biblioteki mogą korzystać jednak nie tylko ci najbardziej zainteresowani wszelkimi gadżetami z logo biblioteki. Można próbować zainteresować ofertą sklepu także osoby, które niekoniecznie szukają pamiątek związanych z biblioteką. Nowojorska biblioteka publiczna stosuje w tym zakresie ciekawe rozwiązanie, łącząc ofertę sklepu z popularnymi okresami wręczania prezentów. Na przykład w okresie poprzedzającym dzień matki ogłasza akcję „Prezent na dzień matki” (Mother's Day Gift), a opisy potencjalnych prezentów odsyłają bezpośrednio do sklepu internetowego NYPL ${ }^{18}$.

Strona startowa nowojorskiej biblioteki publicznej może służyć jako wzorzec dla działań fundraisingowych wykorzystujących potencjał własnej

16 Zob. The British Library. Tryb dostępu: https://www.bl.uk/ [17 czerwca 2017].

17 Zob. The Library of Congress: Tryb dostępu: https://www.loc.gov/ [17 czerwca 2017].

18 L. Price: Digital philanthropy and libraries. W: Successful library fundraising. Best practices. Ed. by M. Sandra Wood. Lanham 2014, s. 184. 
strony internetowej. W menu tej strony znajduje się bowiem jeszcze jeden istotny element fundraisingu sieciowego. To odsyłacz z krótkim i dobitnym hasłem „Give”, który uruchamia rozbudowaną, kilkupoziomową część serwisu New York Public Library (NYPL) z informacjami m.in.: o możliwości zostania członkiem koła przyjaciół NYPL lub wolontariuszem, o spotkaniach dla sponsorów, o programie odroczonych darowizn. Na wstępie tej części serwisu internetowego biblioteki znajduje się następujące wprowadzenie: „Państwowe fundusze pokrywają tylko część kosztów działalności biblioteki. Zależymy więc od wsparcia takich jak Ty szczodrych osób, które pomagają nam utrzymać nasze podstawowe usługi w formie bezpłatnej dla wszystkich nowojorczyków"19.

Głównym elementem tej części serwisu internetowego są informacje dla potencjalnych członków koła przyjaciół NYPL, gdzie zostały wyliczone wszelkie korzyści, jakie mogą uzyskać przyjaciele biblioteki z kolejnych poziomów członkostwa. Poziomy te ustalono następująco:

- Library Associate (wymagana darowizna 25-49 dolarów);

- Friend (wymagana darowizna 50-99 dolarów);

- Supporting Friend (wymagana darowizna 100-249 dolarów);

- Patron (wymagana darowizna 250-499 dolarów);

- Sustainer (wymagana darowizna 500-999 dolarów);

- Sponsor (wymagana darowizna 1000-1499 dolarów) ${ }^{20}$.

W serwisach internetowych bibliotek dość często spotyka się takie strony adresowane do potencjalnych członków kół przyjaciół bibliotek. Często też obok informacji o działalności kół i korzyściach, jakie z tego wynikają, znajdują się wprost podane warunki finansowe, jakie trzeba spełnić, by stać się członkiem takiego koła. Nierzadko też w tych miejscach pojawia się informacja o możliwości wyboru różnych stopni „zaprzyjaźnienia z biblioteką". Polega to na tym, że im wyższa jest zadeklarowana składka członkowska, tym wyższy poziom członkostwa (level of membership) w kole przyjaciół biblioteki i tym samym większy zakres przywilejów.

Strona internetowa biblioteki to też właściwe miejsce, by zachęcić do wzięcia udziału w rozmaitych akcjach fundraisingowych. Wśród nich często spotykane są akcje typu „adopt a book”, do których namawiają zarówno

19 Give. New York Public Library. Tryb dostępu: https://www.nypl.org/give [23 czerwca 2017].

20 Friends of the Library. New York Public Library. Tryb dostępu: https:/www.nypl.org/ support/membership/friends-library [23 czerwca 2017]. 
duże biblioteki naukowe, jak i mniejsze publiczne czy szkolne. Odbywa się to podobnie jak w ogrodach zoologicznych, gdzie donatorzy biorą częściowo na siebie koszty utrzymania wybranego zwierzęcia, za co w podziękowaniu otrzymują odpowiedni certyfikat, a bywa też, że informacja o donatorze umieszczana jest na stosownej tabliczce na ogrodzeniu wybiegu dla zwierząt. Biblioteki, które inicjują podobne akcje, zachęcają donatorów do wpłacania odpowiednich kwot w celu zakupu nowości. Zgodnie z zasadą, że konkretny cel skuteczniej przyciąga fundatorów, biblioteki czasem umieszczają na stronach internetowych listę książek, które chciałyby mieć w swoich zbiorach i których zakup fundatorzy mogliby sfinansować. Bywa też, że w ramach akcji „adopt a book” za pośrednictwem strony WWW biblioteki można deklarować fundusze na konserwację jakiejś kolekcji lub nawet konkretnie wskazanej książki ${ }^{21}$.

Pewną odmianą bibliotecznych działań „adopcyjnych” anonsowanych na stronach WWW bibliotek są akcje zachęcające do zaopiekowania się wybraną częścią księgozbioru pod hasłem „Adopt a bookshelf” (zaadoptuj półkę z książkami). Dość często pod hasłem "Adopt a shelf” biblioteki zamieszczają informacje dla wolontariuszy, których zadaniem jest po prostu zadbanie o porządek w określonym dziale księgozbioru, ustawienie zbiorów według przyjętego systemu klasyfikacji, czasem też odkurzenie. Wymaga to od wolontariusza krótkiego zaangażowania w bibliotece 1-2 razy w tygodniu. W takich sytuacjach wolontariusz ofiarowuje bibliotece swój czas, a nie pieniądze, ale wartość wykonanej pracy bywa czasem wyższa od kwoty darowizny pieniężnej. Poza tym aktywizowanie wolontariuszy i budowanie zespołu przyjaciół biblioteki, to jedno z podstawowych zadań bibliotecznego fundraisera, co dobitnie podkreślają podręczniki fundraisingu.

Zachętę do wzięcia udziału w akcji pod hasłem "Zaadoptuj książkę"(lub podobnym) można czasem znaleźć także na stronach polskich bibliotek - głównie publicznych i pedagogicznych. W polskim wydaniu ma to jednak więcej wspólnego $\mathrm{z}$ propagowaniem czytelnictwa i bookcrossingiem niż z działaniem fundraisingowym, bo w ramach tych akcji biblioteki nie zabiegają o fundusze na zakup książek, a raczej po prostu rozdają książki.

21 Zob. np. Adopt a Book. British Library. Tryb dostępu: http://support.bl.uk/Page/Adopta-book [18 czerwca 2017]. 


\section{Podziękowania jako element fundraisingu}

Nieodłącznym elementem fundraisingu jest uhonorowanie donatorów. Należy więc dziękować nie tylko dlatego, że tak każe dobre wychowanie, ale również z tego powodu, że podziękowania złożone w odpowiedniej formie i w odpowiednim czasie budują dobrą atmosferę do dalszej współpracy. Jednym ze sposobów wyrażenia wdzięczności stosowanym przez biblioteki jest umieszczenie $\mathrm{w}$ widocznym miejscu (najczęściej w holu biblioteki lub na ścianie przy wejściu) tabliczek z nazwiskami najbardziej hojnych osób. Są to tzw. ściany darczyńców (ang. donor walls). Owe ściany są zaliczane do tzw. fundraisingu pasywnego (ang. passive fundraising), bo na ich widok inni potencjalni darczyńcy mogą być zainteresowani przekazaniem donacji. Notabene w poradnikach fundraisingu wręcz zaleca się, żeby w miejscach, gdzie znajdują się takie tabliczki, zostawiać nieco wolnej powierzchni jako zachętę dla kolejnych donatorów ${ }^{22}$.

Strona internetowa biblioteki może także pełnić funkcję „ściany darczyńców". Na początku strony internetowej można zawrzeć szczegółowe informacje o warunkach, jakie należy spełnić, by swoje nazwisko umieścić na zaszczytnej tablicy sponsorów. Nie można powiedzieć, by w praktyce było to całkiem łatwe, bowiem miejsce na ścianie darczyńców zapewniają biblioteki tylko najbardziej szczodrym, a warunkiem może być np. minimalna kwota darowizny w wysokości 1 tys. dolarów ${ }^{23}$. Nazwiska ofiarodawców mniejszych kwot, które z oczywistych powodów nie znajdą się na rzeczywistej ścianie darczyńców, mogą się jednak znaleźć na ścianie wirtualnej. A przecież nie musi to być tylko banalna lista $\mathrm{z}$ nazwiskami w prostym HTML. Darczyńcy będą z pewnością bardziej uhonorowani i być może zechcą rozważyć dokonanie kolejnej darowizny, gdy taka wirtualna ściana będzie graficznie dopracowana i kompozycyjnie przypominać będzie ścianę rzeczywistą ${ }^{24}$.

Oryginalną formą wyrażenia wdzięczności donatorom są ekslibrisy donacyjne umieszczane w książkach przez nich ufundowanych. Niektóre biblioteki zachęcają też swoich użytkowników do poszerzonej formy wspar-

22 J. Swan: Fundraising for libraries. 25 proven ways to get more money for your library. New York, London 2002, s. 119.

23 Zob. np. Donor Recognition. Oceanside Public Library. Tryb dostępu: http://www. ci.oceanside.ca.us/gov/lib/support/donors.asp [18 czerwca 2017].

24 Zob. np. Wirtualna ściana darczyńców Biblioteki Uniwersytetu Zachodniego w London w kanadyjskiej prowincji Ontario. Tryb dostępu: https://m.lib.uwo.ca/support/globallibraryspace/donors/index.html [18 czerwca 2017]. 
cia biblioteki poprzez wykupienie plakietek, które zostaną umieszczone na określonych półkach $\mathrm{z}$ książkami. Taki rodzaj donacji przewiduje np. jedna $\mathrm{z}$ bibliotek kolegialnych Uniwersytetu w Cambridge, proponując donatorom wykupienie za 300 funtów rocznie tabliczki z informacją o darczyńcy, która zostanie umieszczona na wskazanej przez donatora półce z książkami ${ }^{25}$.

Znakiem nowych czasów są jednak nowe, cyfrowe ekslibrisy (ang. digital bookplates). Niektóre biblioteki oferują mianowicie wykupienie wirtualnych ekslibrisów, które mogą kogoś upamiętniać lub być dla kogoś wyrazem wdzięczności. Takie digital bookplates są dołączane do opisu katalogowego książki i wraz $\mathrm{z}$ nim wyświetlane podczas przeglądania katalogu. Program cyfrowych ekslibrisów donacyjnych, prowadzony od kilku lat $\mathrm{w}$ sieci bibliotek Uniwersytetu Zachodniego w kanadyjskim London w prowincji Ontario, opisały Sherry Foster i Jennifer Robinson ${ }^{26}$. Minimalna kwota, jaką należy wnieść za cyfrowy ekslibris powiązany $\mathrm{z}$ rekordem bibliograficznym wynosi $\mathrm{w}$ tym przypadku 150 dolarów. W praktyce działa to w ten sposób, że w polu 856 formatu MARC 21 znajduje się informacja fundacyjna wraz z hiperłączem do pliku graficznego z odpowiednim ekslibrisem ${ }^{27}$.

W ten sposób biblioteka może swoje działania fundraisingowe prowadzić już nie tylko z poziomu głównej strony WWW, ale również z poziomu katalogu online. W ogóle nowoczesne systemy biblioteczne $\mathrm{z}$ generacji OPAC 2.0, bogato wyposażone w rozmaite społecznościowe elementy, pozwalają bibliotekarzom wykorzystywać do gromadzenia funduszy także interfejs swojego katalogu. Coraz częściej spotykana integracja interfejsu OPAC ze stroną biblioteki sprawia też, że najważniejsze elementy strony głównej, a więc także elementy fundraisingowe, jak hiperłącza typu „Donate” czy „Support” są widoczne w trakcie przeglądania katalogu. Można tu jako przykład wskazać katalog Biblioteki Publicznej w Nowym Jorku, gdzie w interfejsie WebPAC Pro dla systemu Millenium użytkownik nie traci z oczu głównego menu ze strony głównej biblioteki, w którym dominuje

25 Sponsor a Shelf. St John's College Cambridge. Tryb dostępu: http://www.joh.cam.ac.uk/ sponsor-shelf [23 czerwca 2017].

26 S. Foster, J. Robinson: Donor recognition and cultivation through the use of digital bookplates. „Journal of Library Innovation” Vol. 3(2) (2012), s. 43-49.

27 Podobną ofertę dla swych użytkowników ma też Biblioteka Uniwersytetu Browna w Providence (stan Rhode Island). Na stronie: https:/library.brown.edu/bookplates/ można zapoznać się z bogatym zestawem cyfrowych ekslibrisów i sprawdzić jednocześnie, z jakimi rekordami w katalogu zostały one powiązane. 
graficznie przycisk „Donate”28. Podobne rozwiązanie zauważyć można w interfejsie katalogu Biblioteki Publicznej w Chicago w systemie Polaris. Pod każdym wyświetlanym opisem $\mathrm{z}$ katalogu użytkownik ma stale dostęp do menu głównego wraz z wyróżnionym w tej części przyciskiem „Support the Library"29.

\section{Zakończenie}

W polskich bibliotekach - zwłaszcza akademickich - sukcesywnie pojawiają się oddziały, sekcje lub przynajmniej jednoosobowe stanowiska, których pracownicy mają za zadanie pozyskiwać dla biblioteki dodatkowe środki. Takich pracowników Jacek Willecki proponuje zaliczać do grupy „bibliotekarzy projektowych zapewniających swoim jednostkom organizacyjnym źródło dodatkowych dochodów, przeznaczanych na finansowanie działań prorozwojowych"30. Owi „bibliotekarze projektowi” to bez wątpienia biblioteczni fundraiserzy, tworzący w polskim bibliotekarstwie nową, ważną specjalizację. Ale biblioteczny fundraising to nie tylko aplikowanie $\mathrm{w}$ dużych unijnych lub rządowych programach. To też pozyskiwanie mniejszych funduszy $z$ innych źródeł, co sumarycznie dać może również znaczące kwoty.

Miejscem, gdzie biblioteka może informować o swoich potrzebach z nadzieją na wsparcie jest jej własna strona internetowa. To za jej pośrednictwem można pozyskiwać darowizny, poszukiwać wolontariuszy, zachęcać do „adopcji książek” i - co ważne w fundraisingu - wyrażać wdzięczność donatorom. Tymczasem na stronach polskich bibliotek elementy fundraisingowe, tak często spotykane w serwisach WWW bibliotek zagranicznych, są spotykane nader rzadko. Należy więc życzyć polskim bibliotekom, by dostrzegły potencjał fundraisingowy swoich stron internetowych i wykorzystywały go w większym zakresie.

28 Zob. New York Public Library Catalog. Tryb dostępu: https://catalog.nypl.org/ [23 czerwca 2017].

29 Zob. Chicago Public Library. Tryb dostępu: https://chipublib.bibliocommons.com/ [23 czerwca 2017].

30 J. Willecki: Aktywność prorozwojowa bibliotek akademickich, związana $z$ działaniami na rzecz nauki i upowszechnianiem nauki, finansowana ze środków Ministerstwa $\mathrm{Na-}$ uki i Szkolnictwa Wyższego w latach 2010-2015. „Przegląd Biblioteczny” 2017, z. 1, s. 31. 
STRONA INTERNETOWA BIBLIOTEKI I JEJ SYSTEM ZINTEGROWANY JAKO...

\section{Bibliografia}

1. Annual online study shows donors 75 and older now giving online. Dunham+-Company. Tryb dostępu: https://www.dunhamandcompany.com/2017/03/ annual-online-study-shows-donors-75-and-older-now-giving-online/ [22 czerwca 2017].

2. Beyond book sales. The complete guide to raising real money for your library. Ed. by S. Dowd. Chicago 2014.

3. The Big Boom in online giving. „The Chronicle of Philanthropy” 2013, june 23. Tryb dostępu: https://www.philanthropy.com/article/The-Big-Boom-in-Online-Giving/150689 [20 czerwca 2017].

4. Cooper T.: Getting the most from donations. „Public Libraries” Vol. 49(2) 2010, s. 31-36.

5. Dunham+Company study: explosive growth in donations via mobile devices. Dunham+Company. Tryb dostępu: https://www.dunhamandcompany. com/2016/03/dunhamcompany-study-explosive-growth-in-donations-via -mobile-devices/ [22 czerwca 2017].

6. Foster S., Robinson J.: Donor recognition and cultivation through the use of digital bookplates. „Journal of Library Innovation” Vol. 3(2) 2012, s. 43-49.

7. Friends of the Library. New York Public Library. Tryb dostępu: https://www. nypl.org/support/membership/friends-library [23 czerwca 2017].

8. Frontline fundraising toolkit. American Library Association. Tryb dostępu: http://www.ala.org/advocacy/sites/ala.org.advocacy/files/content/advleg/ advocacyuniversity/frontline_fundraising_toolkit/fft.pdf [20 czerwca 2017].

9. Give. New York Public Library. Tryb dostępu: https://www.nypl.org/give [23 czerwca 2017].

10. Holt G. E., Horn G.: Taking donations in cyberspace. „The Bottom Line” Vol. 18 , nr 1 (2005), s. 24-28.

11. Online giving makes it easy for your supporters of all ages to donate. W: Online fundraising: the beginner's guide for nonprofits. Tryb dostępu: https://www. mobilecause.com/beginners-guide-to-online-fundraising/online-giving [17 czerwca 2017].

12. Price L.: Digital philanthropy and libraries. W: Successful library fundraising. Best practices. Ed. by M. Sandra Wood. Lanham 2014.

13. Survey shows aging donors most likely to give online. Dunham+Company. Tryb dostępu: https://www.dunhamandcompany.com/2016/01/survey-shows-aging-donors-most-likely-to-give-online/> [22 czerwca 2017].

14. Swan J.: Fundraising for libraries. 25 proven ways to get more money for your library. New York, London 2002.

15. Willecki J.: Aktywność prorozwojowa bibliotek akademickich, związana z działaniami na rzecz nauki i upowszechnianiem nauki, finansowana ze środków Ministerstwa Nauki i Szkolnictwa Wyższego w latach 2010-2015. „Przegląd Biblioteczny" 2017, z. 1, s. 21-33. 